\title{
Globalization as an Affront to Indigenous Cultural World Views: Implications for Africa
}

\author{
IHEJIRIKA, CARDINAL I. C. \\ Department of Philosophy \\ University of Port Harcourt, Nigeria \\ cardinalihejirika@gmail.com, +2348028279646 \\ JUDE, ASIKE \\ Department of Philosophy \\ University of Port Harcourt, Nigeria \\ asikejude@yahoo.com, +2347034332569
}

\begin{abstract}
Globalization espouses the idea of universalization of cultures and economies toward intensified social relations which unite distant localities. Its project cuts across geographical boundaries, cultures and sovereignties with the presumed aims of socio-political and economic development and unity of nations. However, it proposes monolithic kind of unity, which blurs cultural lines, destroys the beauty of cultural diversity, stifles social control, diminishes cultural identities and distinctions thereby lea ding to forced acculturation. Besides creating a moral lacuna by its introduction of foreign ideologies into indigenous societies, globalization (or more particularly, cultural globalization) seems to have left Africans confused and without a defined ideology of life and development. Consequently, the worrisome impression created is that globalization is at best, an Eurocentric agenda. Informed by these inequalities as witnessed by indigenous societies, this paper, which limitedly focuses on the harm of globalization on indigenous cultures (using the African-Igbo as a case study) suggests an adjusted relativist global culture to be called "the cultural pluralism approach". This consciousness-raising process is advanced to check the pitfalls of a context-free global culture, which destroys indigenous cultures. The analytical method is adopted for this research.
\end{abstract}

Keywords: Globalization, Culture, Indigenous Culture, Implication

Academic Discipline / Sub Discipline: Philosophy, Epistemology, Cultural Studies.

Analytical Method: Literary Analysis

\subsection{Introduction}

The unfortunate erosion of time honoured and treasured traditional values embodied in cultural vestiges of indigenous societies has been severally blamed on globalization. Globalization, a multifaceted contemporary economic and socio-political phenomenon elicits several interpretation and reaction, some of which are more often than not negative depending on the perceiver. While the developed Western nations see globalization as a development catalyst, the Africans and other indigenous societies conceive globalization as an exploitative instrument of the West and a form of neocolonialism and marginalization, which as such should be jettisoned. They also trace the loss of their history, values, social norms and their identity and personality to the universalizing inclination of globalization. Such universalization forces other cultures of the world into Western categories. While admittedly, globalization has scored some positive goals of enlightening hitherto closed societies. Its negative effects have taken a great toll of all the realms of indigenous societies' national lives ranging from economic, political, social, ethical, religious and philosophical. Previously held virtues have been eroded away by what Okoro in his "Nigeria and Socio-Economic Globalization of the $20^{\text {th }}$ Century: A Historical Re-consideration" calls the flood of globalization (01). This flood has mercilessly left indigenous societies such as Africa rootless yet, in her own soil and without personality or identity. Worse still, is its effect on the cultural aspect of African life Akande reports thus: 
The aggressive spread of market economies and communication technologies often under the control of western multinationals - brings new challenge to the local cultures and values in Africa and other non-western societies. Sometimes, it seems as if a tribal wave of the western culture is creeping across the globe like a giant strawberry milkshake oozing over the planet, with a flavor that is dialectically sweet, sickly and manifest homogenous (1-3).

With the three forces of modern technology, communication and western ideologically petrified educational prescriptions, indigenous people such as Africans simply bow to these intimidating floods imbibing in the process, the materialist and individualistic values of western culture. That way, the African psyche is damaged by the adoption of a new culture which denies indigenous cultures of personal continental history, rejects indigenous traditional heritages, labeling them as anachronistic and idolatry, encourages acceptance of any novel nonsense once it has a western flavor. This overthrow of indigenous values has been found to only replace a suffocating but stable space with an exploitative, dominant, divisive and discriminative one. This has led to the loss of communality along with the values that make for social control, cohesion and integration. Akande therefore traces African disorientation to the foregoing and warns that this ideological disease manifests variously in one or two extreme forms such as: (1) "Exaggerated attachment to an often-reinvested past in the name of tradition and culture or (2) Attempts at wholesome adoption of anything and everything foreign" (13).

Given the foregoing anti-culture disorientation characteristics of the globalization project and its associated modern scholarship, which plays down the position or importance of indigenous culture, rather, emphasizing logical or theoretical foundations, a dangerous paradigm is brought to birth. The danger lies in the fact that every paradigm is a way of thinking, perceiving, communicating and viewing of the world in other words, a worldview or mindset. Now, every paradigm domiciles in our subconscious categories and manifest therefrom in our habits, which in turn defines or showcases our values giving meaning to our actions and inactions. Bearing in mind that culture in whatever form is often ethno-centric and value laden, the universalization of Western culture through globalization inadvertently must undermine Africa's self definition, self realization and her own unique contributions to the making of a global village. Africa, bereft of culture and social values of solidarity, sense of industry and personal enterprise, spirit of freedom, principle of justice, sense of democracy etcetera is persona non-grata in the world community.

This is because culture and its associated values help man to create the experiences needed in order to theorize and to apply logic. Every culture therefore has its own logic with which its thrives. However, epistemological enquires, daily activities and rationalizations are also based on or applied to cultural experiences as they are revealed in people's daily activities and lifestyles. Emma Etta was therefore right when he asserts that "ratiocinations which eventually lead to knowledge / solutions to a people's problems are most times initiated by cultural existential challenges" (Frontier 09). By this token, culture dictates what gets institutionalized in one or other community as a social practice which eventually becomes contextually acclaimed as knowledge.

Consequently, any foreign orientation which destabilizes harmless indigenous cultural practices and values, disorients the people from their roots. Having been caught in this unfortunate erosion of our cultural values and ideologies in the form of globalization, the question becomes-do we flow with the globalization tide and flush away all the cherished values or do we stagnate ourselves from connecting with the rest of the world in this universalization march? This paper recognizing the dynamism of humanity underscores the fact that both extremes are dangerous rather, and in order to retain our treasured cultural values and identity without estranging ourselves from the rest of the world, there is the need to undertake a deeper philosophical reflection. Consequently, this paper suggests a brand of cultural relativism which is a paradigmatic consciousness-raising and re-orientation process of 'cultural pluralism' as a panacea to the affront of globalization on indigenous cultures. 


\subsection{GLOBALIZATION: HISTORICAL PERCEPTIVE}

Whatever else it may entail, globalization relates to "the intensification of worldwide social relations, which link distant localities in such a way that local happenings are shaped by events occurring many miles away and vice versa" (Giddens 64). Nsibambe incorporates five concepts in his definition of globalization. He avers that globalization is "a process of advancement and increased interaction among world communities and people facilitated by progressive technological changes in locomotion, communication, political and military powers, knowledge and skills as well as interfacing culture value systems and practices" (27).

The primary stimulus of globalization is the deregulation of dependency of national currencies on the dollar, which took place between 1971-1973. Prior to this time and based on the Bretton Wood Treaties of 1944, there had been in existence a system of fixed exchange rates of the world's main currencies dependent on the American dollar. The deregulation of the dependence therefore resulted in a transition to the system of the 'so called free floating exchange rate', which is valid till date. Along the oil crises of 1973, the referred transition culminated in the established of multinational corporations and their expansion to new markets seeking manufacturing opportunities especially in the developing countries. The major aims were therefore economic namely, profit maximization and capital accumulation. Hence, the deregulation of central over capital movement and the possibility to use the above mentioned comparative advantage primarily in members of multinational corporations. In order to get these multinational co-operations firmly rooted, cultures needed to be crisscrossed, sovereignties blurred and geographical lines transversed. It is for this reason that Larson considers globalization as "the process of world shrinkage, of distances getting shorter, things moving closer" (9).

However, kwame reports that political economists interpret globalization as the efforts of the International Monetary Fund (IMF), The World Bank and other financial institutions at creating a global free market for goods and services (16). As a concept, globalization seeks to enhance the deployment of a country's economic, political, technological, ideological and military powers and influence for competitive dimensions in the world. However, globalization is not new to Africa and to the world. Okoro in his "Cultural Globalization the Last Onslaught on African Personality: The Igbo Example" reports Ajayi as submitting that "there has been three major phases of globalization - 1870-1914, 1945-1980 and from 1980 till now (170). This categorization as Kwame observes depends solely on how one defines and explains the concept, globalization (16). In Okoro's words,

Contacts and interactions between Africa and other nations are noted to have existed from primordial times. African history is dotted with European involvements at one time or the other, which significantly defines African history positively or otherwise (28)

However, documentary records show that "African interaction with the outside world particularly, Europe and the Americas date back to the $15^{\text {th }}$ century and this relationship altered the course of African history - culturally, socially, politically, economically etc." (Apparurai, 1996, 7). African contact with the rest of the world, Okoro reports, started with trade relationships, which include the Trans-Atlantic slave trade. This period marked the reaping off and raping of African nations and peoples of their able-bodied men, women and children by the Western to the new world (138). The second major contact between Africa and the Western world was defined by colonialism, which rolled off the ground consequent upon the 1844 Berlin conference resolution approving the scrambling and partitioning of African states. A partitioning which was done with no regard to ethnic, cultural, religious, linguistic and or other definable considerations. The next stage of African interaction with the outside world was the era of independence from the colonial rule (Kwame 03). This final stage culminated in what is technically called globalization today.

It is this latest stage that is of utmost importance to our present work. This is because, the form of globalization which this work discuses and which constitutes the worst affront to indigenous cultures is namely, cultural globalization. By cultural globalization is meant a process of differences of ideas, practices, technology by means of internationalization or universalization of dominant Western ideological practices on less powerful cultural arrangements. Gullein reports that "a cultural ideology of consumerism, driven by symbols, images and anesthetic of life struggle and self image has spread throughout the world (26). Kwame buttresses Gullein's 
observation by asserting that "the most popular and controversial debates about globalization are centered on the rise of a global culture (8). Tomlison in tandem with Gullein and Kwame confesses that "it is fair to say that the impact of globalization in the cultural sphere has, most generally been viewed in a pessimistic light. Typically, it has been associated with the destruction of cultural identities, victims of the accelerating encroachment of homogenized westernized consumer culture" (177). Ihejirika in corroboration opines that the global culture which dominates, annexes and assimilates thereby invalidating long cherished values of indigenous cultures "exchanges necrophilic and sadistic benevolence in return for absolute loyalty, which becomes the greatest tool unleashed to accomplish an unending exploitative structure which projects unity and economic prosperity as marketable commodities while stifling cherished cultures from the backdoor" ("Globalization, African and the rest of us" 46). We have spent much time elucidating the entailments of globalization simply because it is a major pivot on which our critique revolves.

\subsection{CULTURE AND INDIGENOUS SOCIETY: TOWARD UNDERSTANDING.}

\section{(a) Culture}

The word culture derives from the Latin "colere" meaning 'to cultivate', which implies attaining ideas of wisdom for human actualization (Asiegbu and Chukwuokoro 15). The concept, culture is variously interpreted and understood thus lacking a universally agreed definition.

In any case, majority of social scientists agree that culture means much more than just some aspects of human social co-existence. It is an embodiment of the totality of human existence. Peil therefore defines culture as "everything passed down by human society except its biology; hence language and technology, laws and customs, beliefs and moral standards are elements of culture" (Atemie \& Girigiri, 01). For Sanderson, culture is "the total life, ways, characteristic of the members of a society including tools, knowledge and patterned ways of thinking and acting that are learned and shared and are not the direct product of biological inheritance" (Nigeria socio-Cultural Heritage 01). From Sanderson's explication above, we learn that culture is a complex totality consisting of three inter-related sets of phenomena namely: the tools and techniques or simply, the technologies that people invent and adapt to their environment. The patterned behavior which individuals engage in as members of a society and finally, the shared beliefs, values, symbols and rules that human beings create as means of giving meaning to their interpersonal relationship and their interaction with their natural environment.

Culture however, has two basic elements namely, the material and the non-material aspects of culture. Material culture include all artifacts, clothing's, weapons, tools. In fact, all the material products of society. On the other hand, non-material culture has to do with ideas behind the making and transformation of material objects for man's use. These include norms, values, belief system(s), social institution found in any society. This later aspect of culture consists in greater measure, the focus of our discussion. This is because they are chiefly responsible for our habits, actions and inactions. Edgall was therefore right when he defines culture to include "all that people have learned and through cultural facts, peoples thought, actions and feelings are known. Culture for him therefore defines values, attitudes, beliefs, mindsets, cultural tendencies, world views and orientations that are prevalent in a given society (1-8).

Edgell's aforestated definition of culture is adopted as our working definitions for this work. The implication of this however is that from his explication, it is crystal clear that destruction of one's culture is akin to the destruction of one's personhood. As Iwe puts it "the spirit of African culture reflects the basic motivation - its wellestanchauung. Its philosophy vision and interpretation of life, its hierarchy of values and the priorities of its needs and aspiration (141). Okoro adds that "the African and of course any other people are bequeathed with values and norms which are manifested to the external world through their cultural accretion" (31). Culture is simply the vehicle through which man expresses himself. By the foregoing, we discover that culture defines one's place in his environment, time and context thereby making one uniquely relevant in the community of other cultural groupings. Cultural globalization therefore poses a threat to indigenous cultures since it is associated with the distortion and destruction of African and by extension, other indigenous societies' cultural identity. 
Shepard and Hayduck therefore consider globalization as senseless extinction or indeed as a euphemism for western cultural imperialism. It is this cumulative effect of cultural globalization on indigenous societies that is considered a haemorraging affront on values and norms of these societies. But who then are these indigenous cultures?

\section{(b) Indigenous Culture}

Etymologically, the word indigenous is derived from two Greek words namely, 'endo' meaning inside or within and 'genous' meaning birth. Indigenous as a word means to be born within or as a native (Klein 787). By indigenous culture as used in the context of this work, we simply refer to the norms, customs, institutions, values, traditions and ethics of indigenous people, who domicile in a closely-knit environment prior to the advent of foreign influences and accretions. Every society has its indigenous people who are ethnic groups, natives, being descendants of those people that inhabited a territory prior to colonization or formulation of present state. Indigenous culture therefore refers to the cultural patterns of indigenous people, who are protected by international or national legislation as having a set of specific rights based on their historical ties to a particular territory, their cultural and historical distinctiveness from other population. In reference to Africa, indigenous cultures may include all those positive cultural practices of pre-slavery, pre-colonial traditional societies, prior to the advent of globalization. These distinctive practices and values, which mark out one society from the rest, becomes its essence, its identity and its pride. A challenge on such indigenous culture is at one and the same time, a challenge on such society's psyche and the very fabric of their existence.

\subsection{THE THREE AFFRONTS AND IMPLICATIONS OF GLOBALIZATION ON INDIGENOUS CULTURES: THE AFRICAN EXPERIENCE}

We have identified three different platforms or phases, globalization has adversely affected culture in indigenous societies. They are: (a) The Economic Affront (b) The Ideological Affront and (c) The Political Affront. We will now explain the above identified spheres of affront in their turns as well as draw their implications.

(a) The Economic Affront: John Feffer observes that "the common element of capitalism and communism remain at the core of globalization (05). Economic growth therefore becomes considered as countries' Hobson's choice for development. "The World Bank Report on the International Economy" (2004) has shown that through the adoption of globalization, many people in developing countries can now live longer than before and their standard of living has improved qualitatively (142). Granted that globalization through its financial agencies namely, International Monetary Fund (IMF) and The World Bank have cushioned the suffering of pauperized nations; by encouraging trade liberalization, helped economies to diversify in time with its comparative advantages of becoming less dependent on single export market and products; fostered character and intensified interdependence of nations; advanced capitalist and its attendant privatization exercises, which in turn encourages creation of a large body of shareholders etcetera. All this positive sides of a globalized economy are at best a type of a necrophilic generosity. Feffer identifies four major problems with economic growth fostered by globalization as "environmental limits, persistent inequality, over production, and debt" (07). The severity and recurring of failings of African economies is consequent upon the International Monetary Fund and The World Bank development policies.

Ihejirika in his "Implications of Globalization for Pan Africanism" observes that, "the Policies of Both IMF and World Bank in Africa have been seen to have three basic features. One of which is the similarity of programmes and the imposition of uniformed conditionality on Africans, regardless of peculiar conditions of individual nations" (05). These uniformed conditions and programmes are imposed because they are designed by the Fund and Bank to serve the same international objective of strengthening the international market system. It is not because all countries have the same problems - their problems indeed differ. This is why almost all African and other poor countries of the world are made to have balance of payment stabilization and structural adjustment programmes. For example, in Nigeria, Erunke reports that "the government introduced a full blown structural 
adjustment programme with the aim of correcting the so-called inherent distortion and restoring the economy to a path of non-inflationary sustained growth and development with the medium term" (28-33) but it failed.

Besides, a cursory look at economic realities the world over indicates that even as the global Gross National Product (GNP), rises, it is very much unclear who buys all the new products that roll off the assembly lines. World manufacturing companies are daily producing more cars, clothes and toys than the world buys. Consumption has been sustained in large part by debt and Scheffer clarifies that "High levels of debt cannot be sustained indefinitely" (Feffer 07). Achebe in the trouble with Nigeria has gone ahead to condemn what he calls the "Cargocult mentality" (17) of Nigerians which describes the depth and insanity of consumerism prevalent in the African country. There is now, no gain saying the fact that even if the people of the world succeed in buying all produced goods with either cash or on credit, our immediate environment will still be incapable of absorbing all the attendant pollution from factories and the exhaust pipes of cars.

The combined rhetorical tools of free trade, deregulation, monopolies, privatization, market fundamentalism, dependency, free market economy and democracy and transparency further reduce indigenous societies to the wretched of the earth. How else can one interpret the standard condition demanded in the programs of IMF and World Bank which are namely: "massive retrenchment, foreign debt repayment, currency devaluation, trade liberalization, privatization of public enterprises, withdrawal of all subsides, removal of price, exchange and interest rates, regulation, open door policy to foreign investments, drastic budget units, exports promotion, currency auction and general deflation? (Ihejirika 06). Yet, these conditions are applied so uniformly that the IMF and World Bank are infamously regarded as bad doctors that prescribe the same drugs for patients with different ailments. The consequence of all these on indigenous cultures is dependency and poverty of the dependent. On the other hand, true generosity as Freire notes consists of:

Fighting to destroy the causes which nourish false charity. False charity constraints the fearful and subdued, the rejects of life to extend their trembling hands. Real generosity lies in striving so that those hands, whether of individuals or entire people need be extended less and less in supplication, so that more and more they become human hands (Pedagogy 22).

Unfortunately, Okoro opines that: Globalization has not removed the socio-political and economic problems that led the country into adopting the SAP reform, rather, it aggravated it. Uka was therefore right when he asserts that "globalization of the world economy arouses dreams of expanding prosperity, yet, it equally stirs up fear of restless intensification of competition, marginalization and poverty (2004). Richard and Said, who style globalization as "the global expansion of the twentieth century capitalism" report that, "it has aggravated most of the chronic problems of the developing countries, while adding new problems. Most of these problems are still best characterized by "the classical" or "modernist" concept of corporate capitalism, economic exploitation, social inequality and social injustice" (2). Aluko with particular regard to Africa submits that "African continent has suffered and is still suffering from the problems of delayed development. The continent and her people have been victims of exploitation whether in the form of slavery, colonization, neo-colonialism, structural adjustment, international money lending and money changing or the ongoing globalization or traidization" (6). This informs why Roland Vaubel conceives international monetary fund as mere bureaucracy. As he puts it, bureaucracies are interested in power, prestige and amenities. To achieve these objectives, they try to maximize their budget, their staff and their independence (195).

Does the foregoing not suffice as an explanation for why globalization destroys economic relations of indigenous cultures, deprives them of their medium of exchange and replaces that with a currency, which subsequently, gets devalued and in the process, cause an abysmal fall in agricultural interest and production? Does the absorption and intimidation of indigenous cultures into surrendering to massive western economies and co-operations' control not make meaning in the light of the foregoing economic rape? In all these, we found that globalization is a corpus of inequality and divisiveness especially among indigenous cultures. The closelyknit community that held sway during the pre-slavery, pre-colonial and pre-globalization era has become a farce. Africans are no longer their brother's keepers. There is incest everywhere, bloodletting has become the 
order of the day, In Achebe's parlance, things have really fallen apart due to the deep cut of the white man's knife and the center no longer holds. Hence, Ozumba (2010) laments that:

Globalization breaks down old communal ties which held people together... people prefer to extricate themselves from the rather very oppressive and unloving cultural relationship of hate, envy, jealousy and divisiveness, polygamy used to be a front of co-operative action and for providing the needed manpower for family. Today, it has become a crucible for acrimony and infighting... Africans are cultivating the materialistic and individualistic habits and values associated with Western culture (195 - 197).

(b) The Ideological Affront: The ideological challenge to indigenous cultures consists of all false and supportive rhetoric's carefully articulated and projected as positive heuristic to the merits of globalization. This false weltanschauung (worldview) is created to convince its victims that globalization is the best possible world hence, should be welcomed with open arms. The truth however is that behind the veil of this worldview, is the intent to dominate, exploit and subjugate indigenous cultures. We have identified these ideological affronts in the areas of the type of education encouraged and transmitted by globalization, the religio-social arrangements advocated by the same (western agents of globalization and missions) and the tactful denigration of indigenous cultural patterns and their replacement with a sciento-technological epistemology. What do we mean by ideology in the context? The term ideology is a highly emotive concept in contemporary socio-political discourse. Since the introduction of this term by the French philosopher, A.L.C Destutt de Tracy, the subject of ideology has ever been as controversial as it is diverse partly because of a non-consensus by scholars regarding its definition. The New Encyclopedia Britannica, defines ideology as "a form of social or political philosophy in which practical elements are as prominent as theoretical ones, it is a system of ideas that aspires both to explain the world and to change it" (194). Blackburn has it that "ideology refers to any wide-ranging system of beliefs, ways of thought and social action (178), whereas for Nzimiro, ideology is "a system of ideas concerning phenomena especially those of social life, the manner of thinking, characteristic of a class or an individual (11). This later definition tallies with Azikiwe's understanding of the term wherein it is conceived as "a systematic body of concept about human life or culture, which includes a way of life and the thinking characteristic of an individual or group of individuals on a particular aspect of social relations (3).

The commonality in the above definitions is the fact that ideology is a conceptual scheme which holds among human beings and with practical ideas of application. Every ideology therefore serves a targeted purpose and must contain within her persuasive tools that which either convinces, deceives or persuades. Let us now take the identified ideologies of education, science / technology and religion and see how they constitute affronts to indigenous cultural worldview.

(i) Education: Prior to the colonization era, indigenous cultures and societies had a flourishing educational system through which societal values, morals and customs are transmitted to the younger generation. Okoro in his paper, "African Traditional Education: A Viable Alternative for Peace Building Process in Modern African World", vividly captures this picture as he cites Mara, who opines that "African traditional education aimed at inducting the members of the society into activities and modes of thought that conduced to norms and values of the society... African societies were noted for their cultural heritage which was preserved and transmitted from generation to generation through a system of traditional education" (1-2). In Okoro's own words, "the ideas of schooling and education were integrated into the traditional system. The traditional system incorporated the ideas of learning skills, social and cultural values and norms into its purpose and method" (10). Consequently, in African indigenous society, the education of the child rolled off the ground at birth and continued to adulthood. It ably prepared these ones for life among the tribe, village and home. The African traditional education curriculum adopted in this indigenous culture embraced all aspects of human development and included mental broadening, physical fitness such as wrestling, races etc, moral uprightness - derived from retelling of folktales and myths, religious deference, good social adjustment and interaction. Ihejirika tags the corpus of learning at this time "Akonucheism", which symbolizes the embodiment of wisdom, skill and acquired knowledge (53). In African 
indigenous contexts as well as elsewhere, vocations, such as farming, fishing, singing and dancing, weaving, hunting, cooking, knitting, building of houses, mat making and forging of local farm implements and weapons of war-fare were impacted on the youths by elderly and skilled ones. It was indeed a lifetime syllabus. As a result, discipline, moral uprightness, fear of the gods, social control, in fact, moral righteousness was inculcated in the youths unlike what holds sway today.

Regrettably, all these changed right from the early stages of globalization namely colonization hence, at the very early stages of the globalizing attempt which took the form of colonization and paved way for full scale $21^{\text {st }}$ century globalization, the education bequeathed to Africa by her colonizers is the type that nurtured self depreciation of indigenous cultures among indigenous people. Africans, for instance, came to internalize the opinions of the world globalizers (namely, Westerners) have of them as the never-do wells of the earth. They have come to internalize such opinions and now find it increasingly difficult to break free. In Freirean words, "They call themselves ignorant and say the professor is the one who has knowledge and to whom they should listen... given the circumstance which has produced their duality, it is only natural that they distrust themselves" (Pedagogy 38-39).

The local sages and the elderly which were considered custodians of indigenous cultures hardly command any recognition today. In any case, culture is learned and learning processes is not a function of natural inheritance and of course not a genetic transmission rather, learning occurs through a gradual process of absorption from social environment or through deliberate instruction. However, the major medium of this transmission of culture across generations is language. This is why the preservation of values are impossible without language hence, a destruction of language tantamount to a destruction of indigenous culture. This, globalization has succeeded in doing to Africans. Taking the case of the Igbos of Nigeria as an instance, Lady Chioma Ohakim of Imo State, a once First Lady of that Igbo State of Eastern Nigeria in an official unveiling ceremony of Nigeria Premiere Cultural Book - firm Project, "Omenuku - Ogemba" notes with nostalgia that, "it is sad that the indigenous African language and culture are becoming extinct at an alarming rate. With little or no effort from the people and government on the continent to curb the trend... it is frightening to note that about 50 percent of Igbo children cannot speak the language and hardly know their root" (1-3). This loss of language above lamented is inadvertently loss of cultural and self identity. Iwe forewarns that, "any culture that loses itself to another has to that extent become the slave of the latter" (142). The people therefore becomes enslaved once their culture is enslaved. This is because it is our culture that embeds our uniqueness and self identity. All former English, French German, or Polish still have English, French, German or Polish as their lingua-franca while disdaining their aboriginal languages and denigrating them as mere vernaculars. This psychological rape continues on the psyche of indigenous people.

African culture (representing indigenous cultures in the context of this paper) is renowned for its moral awareness, enabled by our different indigenous languages, myths, folklores, cultural heritages, rites and rituals of African (and by extension) other traditional faith. Any educational system therefore, that fails to promote indigenous culture smacks of intolerable acculturation and can at best be the least liberating, least creative and least transforming. This, of course, is the type of education Paulo Freire condemns and tags 'banking system of education'. Freire remarks that,

Knowledge in this misguided system regards men as adaptable, manageable beings... and begins with a false understanding of men as objects. It cannot promote the development of what Fromm in The Heart of Man calls biophily... the banking system of education serves the interest of oppression. It is also necrophilic, based on a mechanistic, static, naturalistic, spatialized view of consciousness, it transforms students into receiving objects. It attempts to control thinking and actions, leads men to adjust to the world, and inhibits their creative powers (Pedagogy 46-51).

All that Freire notes above reflect and manifest in the type of education globalizers spread which only encourage a sciento-technological epistemology. 
(ii) Science and Technology: The impact of science and technology has been enormous on the $21^{\text {st }}$ Century. This knowledge system has little or no concern for indigenous cultures. Nevertheless, it has made marvelous contributions to sharpening up the perspectives and enlightening the worldviews of indigenous people. This include among others, some practical achievements like prevention of diseases by early detection, treatment and cure of infectious diseases, literacy, mechanization of agriculture, production of vaccines, brails which can help the blind to read, enhancing communication through information technology, boosting both the economic sector by E-commerce and transportation sector by mass production of automobiles, speedy airplanes, warships, etcetera. In fact, Ihejirika, in his "Techno-Scienticism and National Development in Nigeria: A Philosophical Reflection" featured in Scientific Revolution, Truth and Technology remarks that, life has been made a lot easier. Research has become the backbone of techno-scientific progress... we have so far been enjoying the fruits of techno-sicentism... yet, it seems we are gradually gaining the whole world but at the expense of humanity" (10).

Morris rightly acknowledges these positive contributions of science and technology when he avers that "advances in science and technology have increased man's power to effect his will and produce the kind of things that his modern civilization demands (38). Unfortunately, the history of science and technology bears witness that no sooner had it gathered momentum than it did force man to fit his values to the rhythm of machines. Man, as Ijiomah in his Humanizing Epistemology writes:

Started to lose his human quality for his human quantity. Even religion which is supposed to source for human sense of worth and moral guidance has been drastically affected by mechanization and formalism of materialism, philosophy has also fallen victim as exemplified by naturalized and re-normalized epistemologies, which neglect human welfare as enhanced by morality and cultural values (vii).

The Western scientific and technological mindset spread by globalization through information technology has further destroyed values of indigenous cultures of which Africa is a victim. Africans today walk half naked on the streets in the name of fashion. African humane spirit is already lost. Today's reality is that Africans are besieged with a conscious projection of false image of science and technology adventure from the West and in the name of globalization.

(iii) Religion: Besides, Western religions promoted by globalization namely, Christianity and Islam have been found to have deprived Africans of their identity by labeling our cultural practices, demonic, satanic, idolatry, pagan, and its practitioners infidels and the unconverted. Granted that some nefarious life wasting and primitive hitherto, traditionally held practices have been dropped as a result of these theistic religions, yet behind the veil of this puritanism is sometimes an economic reason. An early element of commercialization through religion dates as far back as 1883 and could be gleaned from King Leopold II of Belgium's letter to colonial missionaries in the Congo. The King acknowledges the African idea of God but specifically directed his cohorts thus:

Your essential role is to facilitate the task of administrators and industrials, which means you will go to interpret the gospel in the world in such a way it will be the best to protect your interest in that part of the world. For these things, you have to keep watch on disinteresting our savages from the richness that is plenty (in their underground. To avoid that, they get interested in it, and make you murderous) competition and dream one day to overthrow you... (Letter from King Leophold II. 1-3).

This western Christian and Arab-Moslem exploitation of Blackman and denigration of his culture continues today in the guise of a globalised culture. Besides the economic undertone prompting the globalization throttle, Christian missionaries got so soaked in many cultural errors in their gospel 
enterprise. Wakatama summarizes these errors in his book, Independence for the Third World Churches under what he calls 'a dressed-up gospel". According to him, "The problem is not that missionaries are changing cultures but that they are failing to adapt the naked gospel to different cultures after the gospel has been transported to other countries wrapped with the cumbersome paraphernalia of western culture in many parts of African today, African names are called 'heathen' and English names are referred to as Christian. Traditional African dress is also heathen and western dress, Christian". The missionaries condemned most traditional rites of passage and social ceremonies as pagan without any prior study to discover whether the meaning behind those ritual forms was in fact contrary to the teaching of scripture (Onyenechehie 13-14). Some missionaries still hold condemnable the payment of bride wealth in marriage, all African dancing and participation in every custom from cradle to grave, bodily adornments of any type, the list is endless. Yes, these are the very constituents of the peoples' culture which gave meaning to their existence. Having that eroded this integral part of the peoples' existence, Akande notes, "the local cultures cease to serve as a means of constructing social values, reproducing group identity and building up of social cohesion (1-3). Oluwole admonishes against this danger and opines that "culture must not be misunderstood as more stylistic peculiarities or just a reference to antiquity of a people or even worse still, idolatry and other forms of iniquitous reminiscences of a heathen part (13). Rather, it should be interpreted as a people's worldview, their understanding of the nature of being, and the character that defines inter-personal universal relationships.

(c) The Political Affront: Globalization respects no boundaries and sovereignties, like a cankerworm it eats deep across boundaries to achieve profit maximization and total control of less powerful nations and cultures be they African, Asian or otherwise. Prior to the unfortunate visitor, (globalization) indigenous cultures had their political arrangements that ensured relative peace and unity among ethnicities. African traditional society had a viable and fruitful political system that built on a uniquely African sense of communalism, founded on kinship and extended families in a proportion unequalled and unrivalled elsewhere (Ozumba and John 46). Wars were majorly inter-tribal but today the reverse is the case. The principle of social solidarity and republican spirit used to be features of many indigenous cultures. The Igbo tribe for instance, organized themselves around the elders' fora. Elders in this indigenous culture had the responsibility of maintenance and protection of public and civil virtue, by which the people could be animated for public good. Some other indigenous cultures like Yorubas have their Oba and his cabinet doing so whereas the Emirs and Sultans do same for the Hausas/Fulanis of Nigeria. The willingness of the citizens to participate directly in Igbo civil affairs, to identify their good with the common good and to sacrifice for public weal was at the epi-centre of Igbo republican spirit. Okoro (2009) in "Cultural Globalization", reports that:

The republican virtue in the traditional society was considered as the moral sense in the citizens that enable them to pursue the common good. Accordingly, the republican virtue makes it possible for self interest and public virtue not to be disjunctive. Therefore, the republican state generates public affection and mobilizes solidarity and community consideration in feeling and behaviors. This made the Igbo traditional society to be humanistic as it organizes itself to ensure that values are harmonized and at the same time ensure the autonomy of the individual members of the community hence, the traditional Igbo republicanism combines personal enterprise, strive and independent mindedness with moral commitment to solidarity and devotion to common good (33).

This ordered indigenous life has presently given way to liberal democracy preached by Western globalization. The laudable republican Igbo spirit is now replaced by crass individualism and materialism. Uwalaka notes that, "in the modern times, utilitarian and individualistic orientation of the Western liberal theorist, in its pure laissez faire form, as a true expression of the republican spirit has taken over" (33). What we have today are incalculable loss of lives and violence in the name of democracy. In Nigeria context today, elections are won and lost in the bargaining rooms where cash exchange hands. Corruption has become endemic. Justice, which used to be a matter of personal honesty and integrity, incorruptibility, uprightness, frankness and sincerity of purpose is now bought. 
The highest bidder is now the just. With such moral hemorrhage, society daily witness's ascendancy in crime, substance abuse, sexual oddities and lack of respect for constituted authority in both high and low places. These are only but a few regrettable dividends of globalization.

Nowadays, the super powers of the world are sacred cows spreading their business tentacles through multi-national corporations all over the world with reckless abandon and little consideration of the plight of indigenous societies. The Ogoni case in Nigeria is a case in point. Besides, uneven model is created in global affairs where the voice of the world powers swallows up voices of Sovereign nations in global, political and economic debates. Aluko in response to some of these political imbalances asserts that: "The current globalization agenda is everything about socio-political and economic domination of the 'Triad' over every other nations and regions, more especially Africa. In his own words' "what is at the root of what is called Triadization lie under the camouflage named globalization" (1). Aluko's observation Okoro notes, "is based on the fact that globalization has eroded national sovereignty and consequently diminishes the citizens' right of participation in the nation's political affairs by substituting the market for the people" (Cultural globalization 32).

\subsection{THE WAY FORWARD}

Globalization with its features of aggressive spread of market economies, communication technologies chiefly controlled by Western multinationals, has nurtured in unsuspecting indigenous cultures hitherto abhorrent vices of the materialistic and individualist values of western cultures. With indigenous culture decimated, the victims for example, Africans have lost their humanistic culture and other highly prized heritages. Whenever any culture losses itself to another, it has inadvertently, submitted to slavery of that other. What then can be done to salvage indigenous cultures from such massively global disorientation? The challenge here is beyond a re-invention of African or other indigenous cultures' identity. It rather extends to a novel thinking or ideology which can not only aid indigenous cultures to retain their cherished values, organize their societies, solve their present cultural disorders but also to contribute their quota to the making of a common humanity. It is true that every society is known and defined by its unique cultural practices yet, culture is no universal concept. This is because it is not only dynamic but society and geographically based. This is the reason Ozumba (2010) enthuses that, "the destruction of a culture is the destruction of the society which such culture defines" (200). The culture vices in indigenous societies is traced to the failure of people of such societies in rationally selecting aspects of the western culture (behind globalization) which can complement their own cultures. Rather, they ingest the whole lump. Just like no man is an island, no culture can stand aloof as absolutely self-sufficing. To save indigenous cultures such as Africans' from total cutlrual extinction, G. O. Ozumba (2010) comes up with his idea of Integrative Humanism". I.I. Asouzu (2011) proposes his "Ibuanyidanda Philosophy". I. C. Cardinal (2016) espouses his "Akonucheism Philosophy", whereas Okoro (2006) tags his brand of a salvivic ideology, "Glolocalization". The commonality between the foregoing proposals is the building of a community that respects the ideas and values of different cultures forming the said new world community. Such community when formed will neither be Afroncentric, Arabcentric nor Eurocentric, Ozumba (2010), rightly underscores the richness of this approach when he remarks that:

Every culture has what it lacks and what it needs, thus the practice of cultural borrowing between and among cultures. However, in the process of cultural borrowing, there is need for each society to have the right cultural appetite guided by the rational needs of the society per time. The cultural needs of societies differ, therefore, the need for societies to cultivate the right appetite (200).

What is of essence here is unity not uniformity

... In the process of international interactions, there is an interaction of cultures and thus, a borrowing and diffusions of cultures among nation. This is in itself not unusual. But unusual and unfortunate is the domination of one which has generated a lot of controversy with regards to the rise of a global culture. In the rise of a global culture, Western norms are practices and 
gradually being transported across the globe as the standard and acceptable way of behavior, Africa is the hardest but in this regard, the hitherto rich, cherished and dynamic African culture has been diluted if not totally eclipsed (Philosophical Paper and Reviews 1-8).

In order to achieve our goal of reversing this regrettable trend, this paper proposes a brand of cultural relativism to be called "Cultural pluralism". Cultural pluralism conveys the idea of an adoption of a global culture which borrows from the idea of religious pluralism. Lev Vygotsky before now notes the fundamental role of social interaction in the development of cognition "He believes that community plays a central role in the process of making meaning" (Frontiers 15). He argues that our cultural beliefs, values, tools of intellectual adaptation of our cultures affect our cognitive functions thus leading to our development or underdevelopment. Whatever an individual knows is guided and ordered by the background of his culture. Since we all think and know through our cultures, there is then the need to harness from our different cultures, relevant values that could still be sustained within the practical framework of globalization in the light of the above, Steve Biko regarding Africa writes:

We regard our living together not as an unfortunate mishap warranting endless competition among us but as a deliberate act of God to make us a community of brothers and sisters jointly involved in the quest for a composite answer to the varied problems of life, hence in all we do, we always place man first hence, all our actions are usually joint community oriented action rather than individualism (42).

In Paul Tillich's words, "The African roams the world fully rooted without a doubt that he never walks alone. He is on the contrary, a member of an extended family" (92). Besides such "communal knowledge that raise this awareness and consideration of community, (for Abanuka) has the individual as its subject and takes to rise from the needs of common life in the community and its end is also the preservation of the community's life and heritage or laws, customs and traditions" (74). In this work, we are of the opinion that while the adjusted interest of a universal $b$ beneficence of globalization is served, individual cultures need not divest themselves of their peculiarities. Rather, the positive elements and heuristics of all cultures could be blend eclectically to serve the good and common purpose of the common human community. As Olajide rightly remarks "Africans as it were have been globalised and have since stayed globalised not only by fact of their heritage but by a sense of beingness within an integrated where whole identities are unique and at the same time affirmed as common and shared" (Personhood 137).

Our proposed vent from cultural crises in indigenous societies namely, cultural pluralism promotes affinity of diverse pertinent and rich values, it believes that there is more in common purpose and utility, which bands than that which divides. Huntington tells us of a Hindu belief which teaches that all great religions of the world are not only relevant but also necessary in the context of the diversity of human needs" (43). The same could also be said of culture. Blyden therefore enthuses that, "every race posses something that is absolutely essential for the completion of the whole, and which other people do not have. In the music of the universe, each shall give a different sound, but necessary for the great symphony" (Tarikh 13). If the foregoing is true, then our cultural pluralism will provide institutional framework by which different values in different cultures are studied for better appreciation and application to the interest of all countries forming the globalised community. Under this framework, a common dynamic global culture can be evolved for the guidance and regulation of globalization. If this is done, possibilities and the potentials of the human community will be guaranteed without much friction. Cultural pluralism engenders mutual respect, dependency and collaboration among diverse cultures of a globalized world. When common respect and values are recognized no matter its land of descent, the globalized world will be built into a formidable and closely Knit human community devoid of either a cultural clash and/or forced acculturation. Kanu in his paper, "Igbo Traditional Humanism: A critical study" affirms that this community spirit as found among the Igbos shows that:

Man, in African traditional culture is not just an individual, who "contracts' to live with others in society, and presumably opts out if the balance of advantages is no longer favorable. Rather, 
the African man is first and foremost a member of his family, the community and his society in that order before being an individual... (Truth, Knowledge and society 311 ).

If such globalised community will become a reality, cultures all over the world need identify with one another, recognize one another's values and dignity. Without such identification, and recognition, the tendency to disdain, exploit, intimidate for parochially selfish ends will continue in the name of globalization. The more this exploitative tendency perdures, the more a fully globalized world community eludes humanity.

\subsection{CONCLUSION}

We have so far tried to examine the propriety or otherwise of adopting a global culture which is inimical to indigenous cultures. In our discussion, we found out that culture, as a way of life serves as the springboard where-from men derive the charter that guides their relationship with fellow human beings as well as their physical environment. It is also culture that more often than not, directs how people think, relate with supernatural beings and how feelings are expressed both within different social groups and without. Briefly put, culture is found to embed our mental processes, beliefs, knowledge and values. Consequently, the destruction of indigenous cultures, which globalization encourages tantamount to an ideological and mental rape of the psyche of people living within indigenous cultures. We noted that a global culture which sees nothing good in indigenous cultures make aborigines aliens in their own homeland. By divesting them of their local language, religion, indigenous dress-sense, traditional ethics, people of such cultures (having been deprived of their self identify and unique personality), become confused citizens of no country, living out no defined ethics of life. In such a social arrangement, society becomes rift with ascendancy in rape, substance abuse, abduction, terrorism of all sorts, corruption etc. Life therefore becomes directionless and meaningless since there are no definable values other than capitalist materialism, crass individualism and politicization and merchandizing of religion. These social evils are all manifest in the economic, ideological and political affronts constituted by globalization as discussed in our paper. However, just as Achebe rightly observes that: "every generation must recognize and embrace the task it is peculiarly designed by history and by providence to perform" (Asiegbu \& Chukwuokolo 2014 27), it becomes our challenge to confront the cosmetic global culture which has impeded the process and development of indigenous cultures such as Africans. In consonance with this passion, Ake (1982) Mazrui (2002), Nabudere (2002) and Nyuot Yoh (2004) as quoted by Okpanachi in his paper "Reconstructing Post Colonial Epistemology in the African Context: Lessons of Boarder Thinking, which featured in Frontiers of Knowledge in Philosophy: cutting edge Issues, share the observation that in an effort to be part of the global system of knowledge production, social science scholarship in its application to Africa (and by extension other indigenous cultures - additions mine) is a central apparatus of expatriate intellectual domination of the continent, which agenda has been to ensure the realization of capitalist and imperialist interests around the world" (67).

What is needed at this juncture is an epistemology of development that will not only retain our cultural uniqueness, identities and personalities but ensure the universal beneficence of globalization without the abuse or total denigration of relevant values embedded in the cultures of indigenous and all other societies. We found a replacement of the prevailing ideologies of globalization which is an exploitative, dominant and discriminative one in our proposal of an adjusted and dynamic global culture pattern which we technically call "the cultural pluralism approach". This approach combines in an eclectic fashion the relevant and cherished values of all indigenous cultures, which are universalizable and incorporate them with those found both in the cultures of the presently developed, developing and even the 'so called' primitive societies. The adapted global culture respects the positive heuristics of all cultures without culminating in a loss of any unique identity of any particular culture. As Paulo Freire notes in his Pedagogy of the Oppressed "No pedagogy which is truly liberating can remain distant from the oppressed by treating them as unfortunates and by presenting for their emulation models from among the oppressors" (30). This therefore calls for Solidarity with the indigenous cultures, which requires that one identifies with them in a radical posture "Concern for humanization (of the dominated and denigrated cultures additions mine) must as a matter of necessity lead to the recognition of dehumanization, not only as an ontological possibility but as an historical reality "(Pedagogy 20 ). 
In order to upturn the depersonalization and the dehumanizing effects of globalization, consciousness-raising, which aims at removing distortions already inflicted on the minds of indigenous people needs be undertaken. To re-orientate the people in this light, demands an epistemological stitching together which binds by way of cultural pluralism, all cultures in a mutually respectful way. That eclecticism of the positive values of these cultures remains the only way that will appropriate to all people of all nations, the much-trumpeted universal benefits of globalization while simultaneously retaining cultural identities and uniqueness that differentiate one people from another.

\section{Works Cited}

Abanuka, B. A. New Essay on African Philosophy. Nsukka: Spiritan Publications. 1994 (Print).

Achebe C. There was a Country - A Personal History of Biafra. New York: London: Little Brown and Coy. 1986. (Print).

C. The Trouble with Nigeria, Enugu: Fourth Dimension. 1989.

Akande, W. "Global Forum: The Draw Backs of Cultural Globalization" Yellow Times, November 2002. (Web).

Aluko, S. The Economic and Political Failure of Globalization in Africa. Akure: Daystar 2002. Print

Anikpo, M.O.C and Atemie, J. D. (editors) Nigeria's Socio-Cultural Heritage. Choba: University of Port Harcourt Press. 2010 (Print).

Apprarurai. Modernity at Large - Cultural Dimensions of Globalization. Minneapolis: University of Minneapolis. 1996. (Print).

Asiegbu, M. and Chukwuokolo, J. C. (editors). Frontiers of Knowledge in Philosophy: Cutting Edge Issues. Enugu: Jones Communications Publishers. 2014 (Print).

_ Personhood and Personal Identity: A Philosophical Study. Enugu: Snaap Press Ltd. 2010 (Print).

Asiwaju, A. I. and Crowder, M. (editors). Tarikh, Vol. 6, No. 3, Pan Africanism, London: Longman Group Limited, 1980 (Print).

Asouzu, I.I. 50th Inaugural lecture of University of Calabar "Ibuanyidanda and the Philosophy of Essence" Calabar: University of Calabar Press, delivered on 18th May, 2011. (Print).

Atemie, J. D. and Girigiri, B. K. "The Concept of Culture". Nigeria Socio-Cultural Heritage, Choba: University of Port Harcourt Press 2010 (Print).

Azikiwe, N. Ideology for Nigeria: Capitalism, Socialism or Welfarism? Lagos: Macmillan Publishers. 1980 (Print).

Babalola, E. O. Christianity in West Africa. Nigeria: Publications International, 1976. (Print).

Biko, S. I. Write What I Like. New York: May Knoll. 1978 (Print).

Blackburn, S. Oxford Dictionary of Philosophy, London: Oxford Publishers. 1999. (Print)

Chukwuokolo, J.C. "Afrocentrism or Eurocentrism: The Dilemma of Africa Development". Ogirisi a New Journal of African Studies, Vol. 6. 200924 (Print).

Edgell, A. "Globalization and Cultural Encounter". International Third World Studies Journal and Review. 2008. Vol. XIV. 1-18 (Print). 
Erunke, C. E. "Rethinking SAP as An Indegenous Socio-Economic Development Strategy: A Re-Appraisal" Development Issues. Vol. 8. No. 1, 2009 (Journal Article).

Feffer, H. (editor), Living in Hope: People Challenging Globalization. New York: Zed Books, 2002 (Print).

Freire, P. Pedagogy of The Oppressed, Ringwood: Penguin, 1972 (Print).

Giddens, A. The Consequences of Modernity, Cambridge: Polity. 1990 (Print).

Gullein, A. Global Culture in the Making. www.newworld.co.uk. Retrieved. August 16, 2016 (web).

Hebding, E. and Glick, L. Introduction to Sociology. Fourth Edition. New York: McGraw. 1992 (Print).

Hutington, S. P. The Clash of Civilization and the Remaking of the World Order. New York: Touchstone. 1996 (Print)

Ihejirika, C. "Globalization and the Rest of Us". Insights, A Journal of the Humanities and Sciences, 2013. Vol. 3. No. 2. Aba Diocesan Press (Journal Article)

"John Dewey's Instrumentalism: A Critique", A Ph.D Thesis, Port Harcourt, University of Port Harcourt, 2016. (53-67) (Unpublished Thesis).

"Techno-Scienticism and National Development in Nigeria: A Philosophical Reflection". Scientific Revolution, Truth and Technology. Emedolu, C. (editor) Aba: Rex Publishers 2014 (print).

Ijioma, C. O. Humanizing Epistemology, Owerri: A. P. Publishers, 1996. (Print)

Iwe, N. S.S. Socio-Ethical Issues in Nigeria. Obosi: Pacific Publishers 1991. (print).

Jenkins, O. B. "Dealing with Cultural Differences: Contrasting the African and European Worldviews" <http://strategyleader.org.2010.12-18 (web).

Kanu, M. "Igbo Traditional Humanism: A Critical Study". Truth, Knowledge and Society. Asiegbu M. and Chukwuokolo, C. J. (editors). Abakiliki: Pacts G. M. Press 2012 (Print).

Klein, E. A Comprehensive Etymological Dictionary of The English Language. Vol. I. A-K New York: Elsevier, 1966 (Print).

Kwame, Y. The Impact of Globalization on African Culture. Denmark: University of Southern Odense. 2008. (Print).

Larsson, T. The Race to the Top: The Real Study of Globalization. Washington D. C: Cato Institute. 2001 (Print).

Letter From King Leopold II of Belgium to Colonial Missionaries, 1883" Courtesy of Mrs Vera Nobles and Chiedozie Okoro retrieved from http://allafrica.com/stories/200510060035.html on 16 October, 2016.

Mara, J. "The Virtues and Challenges of Traditional African Education Journal of Pan African Studies. Vol. 1, No. 4 June 2006. 15-24. (Print).

Matinez J.C. "State of the Indigenous People Report". 1986/7, 379-382.

Mazrui, A. "Pluralism and National Integration". Pluralism in Africa Barkley University of Carolina Press. 1971 (Print).

Morris, L. The Abolition of Religion. London: Inter-Varsity Fellowship, 1964. (Print).

Njoku, F. Essays in African Philosophy, Thought and Theology. Owerri: Clacon Communication. 2002 (Print).

Nsibambi, A. Understanding Globalization. Nairobi: Moi Research Centre December 2008. (Print). 
Nyout, Yoh, J. G. "Decolonizing the African. Mind: The Impact of the Western Culture on Higher Education Systems in African. A Paper Presented at the 16th Annual Conference of Nigerian Studies and Development (IANSD), under the theme "Redeeming the Future: Strategic Initiative for Growth and Development in Nigeria" held at Pioneer Hotel, Abuja, Nigeria. July 28-31, 2004 (Conference Paper).

Nzimiro, I. "History of Evolution of Ideology" New Nigeria Newspaper, Kaduna, April 19, 1977.

Okoro, K. N. "Cultural Globalization, The Last Onslaught On African Personality: The Igbo Example", International Journal of Philosophy and Religion, 2009 Vol. 1, No. 1, 26 - 38 (Journal Article).

"Nigeria and Socio-Economic Globalization of The $20^{\text {th }}$ Century: A Historical Reconsideration", International Journal of Development and Sustainability, 2012, Vol. 1; No. 3. 8. 834-859 (Web).

"African Traditional Education: A viable alternative for Peace Building Process in Modern Africa", Journal of Alternative Perspectives in the Social Sciences, 2010. Vol. 2. No. 1,136-159.

Okpanachi, A. I., "Reconstructing Post Colonial Epistemology". Frontiers. Asiegbu M. and Chukwuokolo, J. C. (editors). Enugu: Jones Communications Publishers. 2014 (Print).

Oluwole, S. B. Philosophy and Oral Tradition. Lagos: African Research Konsultancy. 1999. (Print).

Onyenechechie, T. Rethinking Christianity in Africa. Lagos: Adecrown, 2008. (Print).

Ozumba, G. O. Philosophy and Method of Integrative Humanism, Calabar: Jochrisam Publishers, 2010 (Print).

Ozumba, G.O. and John, E. O., African Political Philosophy, Uyo: EC John Publishers. 2012 (Print).

Richard, D. Economic Globalization: Deepening Challenge for Christian. Geneva: WCC. 1998 (Print).

Sanderson, S.K. Macrosociology: An Introduction to Human Societies. New York: Harper and Row. 1988 (Print).

Shepard, B. and Hayduk, R. (editors) From Act up to the W.T.O Urban Protest and Community Building in the Era of Globalization. London: Verso 2002. (Print).

The New Encyclopedia Britannica, Vol. 9, Chicago: William Benton Publishers, 1943 (Print).

Tillich, P. The Courage to be. London: Yale University Press. 1952 (Print).

Tomlison, J. Globalization and Cultural Identity. www.polity.co.uk. Retrieved. August 16, 2016 (web).

Uka, E. M. "Impact of Globalization on the Third World Economy: A Gospel Response" A Paper Presented at the International Conference on Global Economy and Pastoral Care and Counseling and Religious Traditions at Bangalore, India. August 8-15, 2014. 1-10 (Conference Paper).

Uwalaka, J. The Struggle for Inclusive Nigeria: Igbos to be or not to be? A Treatise on Igbo Political Personality and Survival in Nigeria To Nwaigbo. Owerri: Snaap. 2003 (Print).

Vaubel, R. Bureaucracy at the IMF and The World Bank: A Comparison of the Evidence. London: Mcgraw Hill Books.

Wakatama, P. Independence for the Third World Church. Illinois: Intervarsity Press, 1976. (Print). 


\section{Authors' biographies}

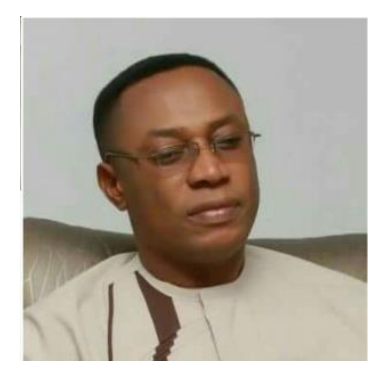

(1) Dr. Cardinal Ihejirika, holds a B.A (2 ${ }^{\text {nd }}$ Class Upper Division), PDGE (Kaduna), Dip. Theo. \& Rel. Studies (Umuahia), M.A, Ph.D (UPH). His area of specialization is in Philosophy of Science and Epistemology. He is currently researching on Cultural Epistemologies and has research interest in Philosophy of Education. He lectures in the Department of Philosophy, University of Portharcourt.

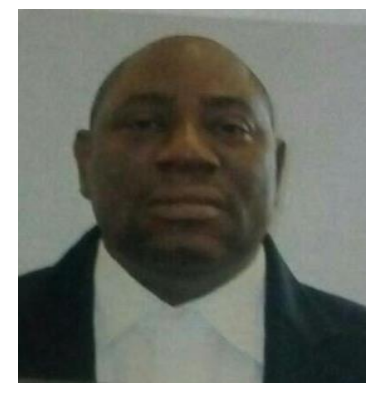

(2) Dr. Jude Asike, holds a B.A M.A, Ph.D. His area of specialization is in Philosophy and Development with an interest in Philosophy of Peace and Conflict Resolution. He lectures in the Department of Philosophy, University of Portharcourt. 